concerned with the relating of a historical narrative. Also, even though geology makes use of very general physical laws for explanation of particular facts, this does not detract from its status as history, for its chief concern is with the particular facts themselves and not with particular facts regarded as tests of physical laws. Thus, a geologist doing a radiometric survey of some minerals is not concerned with the physical basis of $\boldsymbol{\beta}$ decay. As regards to the natural sciences, however, it is worthwhile to emphasize that their general statements cannot be asserted as empirically warranted except by establishing and using singular statements. Kepler formulated his laws to apply only to the solar system. The extension to any system of bodies gravitating under an inverse square law is a generalization. Similarly, we could suppose it to be a biological law that a leopard cannot change its spots. When this is expressed in the form: $(x)(x$ is a terrestrial leopard $\supset x$ cannot change its spots), it is true everywhere. The detail of biological evolution on our planet is a study in terrestrial history. Nevertheless, it would seem a legitimate function of biologists to concern themselves with propositions about evolution, which are more general in the sense that they are applicable anywhere and at any time in the universe, for example, the statement that carbon is essential to any life form may be true, or it may be false. It would be interesting to know which ${ }^{9-11}$.

\section{Other Points}

The remaining points of Crowson's article I shall deal with very briefly. Empirical ethical theories have been influential at least since the time of Bentham. The manner in which shape words, lens-shaped, grooved, and so on, which are deliberately vague are accounted for within the framework of a fairly orthodox empiricism, is discussed by Hospers ${ }^{12}$. Bergson's theory of time has some romantic appeal, but little else to recommend it. I do not think that Husserl's theory provides any trouble for an identity thcory of mind (central state materialism). When one says: "I am thinking about the Melbourne Cup", only a rough similarity of abstract structure of brain states and the physical event, which is the horse race, is required. There are various discussions of the intentionality of our thoughts in ref. 4.

One point of methodology in which Crowson acquiesces seems to me particularly undesirable. He would wish to claim that while phenomenology is an appropriate belief for natural historians, it is not (at present at least) appropriate for natural scientists. (In fact, at least one quite eminent mathematical physicist was, at one time, influenced strongly by Husserl's phenomenonology ${ }^{13}$.) To take this line seems to me to give up too easily. I would judge the attempt to see the world as a complete whole to be worthwhile for its own sake.

1 Crowson R. A., Nature, 223, 1318 (1969).

${ }^{2}$ Nagel, E., The Structure of Science (Routledge and Kegan Paul, London, 1961).

${ }^{3}$ Quine, W. V., The Two Dogmas of Empiricism, the revised version published in From a Logical Point of View (Harper Torchbooks, New York, 1963).

${ }^{4}$ Putnam, H., in Dimensions of Mind (edit. by Hook, S.) (Collier Books, London, 1961).

S Smart, J. J. C., Between Science and Philosophy, ch. 9 (Random House, New York, 1968).

6 Whitehead, A. N., and Russell, B. A. W., Principia Mathematica, second ed., ch. 3 of the Introduction (Cambridge University Press, 1927).

${ }^{7}$ Russell, B. A. W., My Philosophical Development, 238 (Allen and Unwin, London, 1959).

'Isaak, G. R., Nature, 223, 161 (1969).

9 Nagel, E., Scientific Monthly, 74, 162 (1952)

10 Nagel, E., Philosophy and Phenomenological Res., 11, 327 (1951).

11 Smart, J. J. C., Between Science and Philosophy, ch. 4 (Random House, New York, 1968).

12 Hospers, J., An Introduction to Philosophical Analysis (Routledge and Kegan Paul, London, 1961).

13 Born, M., Bertrand Russell-Philosopher of the Century (edit. by Schoenman, R.) (Allen and Unwin, London, 1967).

\section{Dr Crowson replies:}

SADLER's comments on my article on science and phenomenology provide almost a textbook example of the mutual misunderstandings which are liable to affect communications between practising scientists on the one hand and formal philosophers on the other. Sadler writes in the manner of a professional philosopher, judging ideas by current academic standards of logical coherence. In this sphere, he is no doubt much better qualified to speak than I, and it would be very rash of me to try to criticize his logic. My article was, however, written-though perhaps this was not made sufficiently clear at the time-from the point of view of a natural historian, after seeking in the writings of various schools of philosophy for a fundamental intellectual attitude which could be reconciled with his own intellectual practices and experience. In the domain of natural history (which is more fully defined and discussed in ref. 1), I have considerable experience and may well be better qualified to draw general conclusions than is Mr Sadler.

One point of agreement between us is that, in his phenomenology, Husserl tried to reassert the fundamentality of perceived things as opposed to mental schemata; this attitude would tend to link Husserl with natural history rather than natural philosophy. Sadler maintains, however, that "there is no very deep distinction between natural science and natural history"; Aristotle is cited for the opinion that natural science is "more philosophical and of graver import" than history. For the Stagyrite, however, history would have meant human history only, and natural science would have included natural history, so that the quoted opinion is strictly irrelevant to this discussion. Sadler, incidentally, never makes it quite clear whether his "natural science" is equivalent to my natural philosophy.

The most difficult issues involved in the differences between us are concerned with contingency. The concept of the contingent seems to be present in one form or another, more often implicitly than explicitly, in most previous philosophical systems, although I have yet to read a work which provides a satisfying definition and treatment of it. Sadler's colloquial definition, that an event is contingent "if it may or may not happen", is probably as useful as any of the more elaborate ones I have seen. According to anti-historicist philosophers like Karl Popper, the whole of (human) history is a catalogue of contingencies, so defined. It would be a logical extension of the Popperian attitude to apply it also to the entire domain of organic evolution and its products, comprising the subject matter of virology, bacteriology, botany and zoology. In most academically respectable philosophical systems, to refer any phenomena to the realm of the contingent is to banish them to a sort of limbo, where no philosophical significance is to be found.

For positivists, Cartesians and similar schools, the whole domain of natural history is liable to be cquated with that of contingency, and thus to be excluded from serious philosophical consideration. Sadler deplores my suggestion that no formal philosophical system yet proposed, which would satisfy his canons of logical coherence, could provide an adequate intellectual basis for all types of human activity, scientific, artistic, moral and political. Regrettable or not, this seems to me to be a plain statement of fact, exemplified by the failure of current scientific philosophies to attribute any philosophical significance to natural history. It is entirely characteristic that the name of Charles Darwin, and the topic of organic evolution, make no appearance in the index to The Logic of Scientific Discovery. I agree with Sadler in wishing that we could all share a universal philosophy, but suspect that, if such a philosophy ever comes to exist, it will violate some of his canons of logical coherence.

Department of Zoology,

University of Glasgow

1 Crowson, R.A., Classification and Biology (Heinemann, 1970). 